\title{
TROOS AS UNIEKE UITKOMS IN 'N PASTORAAL-NARRATIEWE BENADERING TOT ROUSMART
}

Author:

Alfred R. Brunsdon ${ }^{1}$

\section{Affiliation:}

${ }^{1}$ Departement

Praktiese Teologie,

Noordwes-Universiteit,

Potchefstroomkampus,

Suid-Afrika

\section{Correspondence to:}

Alfred R. Brunsdon

e-mail:

arbrunsdon@gmail.com

\section{Postal address:}

Posbus 10049, Lichtenburg

2740, Suid-Afrika

\section{Keywords:}

narratiewe benadering rousmart; troos; unieke uitkomste; pastorale begeleding

\section{Dates:}

Received: 01 Junie 2009

Accepted: 19 Aug. 2009

Published: 30 Oct. 2009

How to cite this article: Brunsdon, A.R, 2009,

'Troos as unieke uitkoms in 'n pastoraal-narratiewe benadering tot rousmart', HTS Teologiese Studies/ Theological Studies 65(1), Art. \#275, 7 pages. DOI: 10.4102/hts.v65i1.275

This article is available at:

http://www.hts.org.za
(C) 2009. The Authors. Licensee: OpenJournals Publishing. This work is licensed under the Creative Commons Attribution License.

\section{ABSTRACT}

Consolation as a unique outcome within a pastoral-narrative approach to grief The pastoral counselling of those who grieve poses new challenges to pastoral care. Because of the shift away from a modernist paradigm, the grief process is now seen as an open-ended process, rather than a closed process that focuses on the mastering of the so-called tasks of mourning, and the avoidance of grief pathology. Recent grief theory suggests that the grief process cannot reach a point of closure. Grief counselling should therefore rather embark on a process of generating new meaning to the problem-saturated discourses surrounding death and loss. Narrative therapy is suggested as a means of grief counselling, as it makes use of the story analogy, which supports the notion of an open end to the grief process. In this study, the narrative is explored within the framework of Practical Theology. Both the master story of God and the grief-saturated stories of people are combined in a pastoral approach that envisages consolation as the unique outcome of the therapeutic process. Consolation is regarded as one of the secondary narratives in the greater narrative of God, as well as in the reformed theological vocabulary. It is suggested that a pastoralnarrative approach to grief will generate the consolation needed by the grief-stricken on their lifelong journey of coming to terms with their loss.

\section{INLEIDING}

Die pastorale begeleiding van persone met rousmart ná 'n naasbestaande se dood stel tans nuwe uitdagings aan die pastor. Dié toedrag van sake is grootliks toe te skryf aan die huidige wegbeweeg van die modernistiese denkraamwerke wat sedert Freud se routeorie van die vroeë 1900's ons denke oor rousmart oorheers het.

Benaderings vanuit 'n modernistiese raamwerk het die pastor veral in die rol van 'n, beoordelaar van die sogenaamde rouproses geplaas. Die hulpverlener moes toesien dat die rouproses 'suksesvol' afgehandel word. Dít sou wees wanneer treurende persone weer begin energie belê in nuwe verhoudings en ideale (Kübler-Ross 1969; Spiegel 1977), of as naasbestaandes nie meer patologiese rou toon nie. Patologiese rou word beskou as byvoorbeeld die volgehoue ontkenning van die verlies, en die uiteindelike verwerping van hulp (Smith \& Dreyer 2000:279). Indien hierdie uitkomste na die oordeel van die pastor bereik is, sou die rouproses as afgehandel beskou kon word.

Tans gaan daar egter stemme op wat meen dat die rouproses 'n oop einde moet hê, aangesien rousmart nooit werklik as afgehandel beskou kan word nie (Kübler-Ross \& Kessler 2005:158). 'n Nuwe paradigma vir die begrip van rou is derhalwe aan die ontwikkel, waarbinne die korrekte hantering van rou gesoek word in die rekonstruksie van sin en betekenis in die lewens van mense nadat hulle ' $n$ naasbestaande verloor het. Hierdie proses van betekenisskepping (Nadeau 1998:14), eerder as die blote kliniese nakoming van 'routake', neem nou 'n kernplek in die hantering van rou in.

\section{DOELSTELLINGS VAN DIE NAVORSING}

Indien daar aanvaar word dat ' $n$ nuwe paradigma vir die begrip van rou ontwikkel het, moet die pastoraat ook in sy omgang met treurende persone daarop reageer. Derhalwe wil hierdie navorsing die narratiewe benadering tot terapie as modus van pastorale roufasilitering aan die hand doen. Aangesien so 'n benadering met 'n sogenaamde storie of teksanalogie werk (White \& Epston 1990:910), sluit dit aan by die gedagte dat mense ná die ervaring van verlies sin konstrueer deur die oorvertel van ou narratiewe én die vorming van nuwe narratiewe, om só uitkomste te skep wat in moeilike omstandighede hoop verleen.

Enkele implikasies hiervan is dat die uitkoms van die pastorale proses elders gesoek moet word as in die 'suksesvolle' afhandeling van die rouproses, en dat die pastor se rol sal verander van beoordelaar na medereisiger op ' $n$ reis waarvan die einde nie vooraf met ' $n$ afstandsbordjie aangedui word nie.

Hierdie navorsing grond die doel van die pastorale proses op troos as die unieke uitkoms wanneer pastor en pastorant ná die verlies van 'n geliefde op weg gaan. Troos verteenwoordig nie die eindpunt van die rouproses nie, en is ook nie 'n poging om die verlies onklaar te maak nie. Dit skep egter 'n ervaring wat pastorante bemagtig om hulle verlies te hanteer.

Daar sal gepoog word om die navorsingsdoelwitte binne die raamwerk van die Praktiese Teologie te bereik. Dít beteken dat die navorsing die beklemmende diskoers van rousmart as uitgangspunt neem, maar wel soos dit onder die sambreel van die groter narratief van God beskou word soos die Bybel dit verwoord. Müller (2005:73) merk in hierdie verband dat Praktiese Teologie plaasvind 'whenever and wherever there is a reflection on practice, from the perspective of the experience of the presence of God'. Dié opmerking sluit aan by Pieterse (1993), wat Praktiese Teologie binne die paradigma van die kommunikatiewe handelingsteorie geplaas het ten einde die pastorale optrede se vertolkingsfunksie op die voorgrond te bring. Die benadering wat in hierdie navorsing voorgestaan word, probeer egter 
nie die menslike ervaring bo die tersaaklikheid van die Woord stel nie. Die navorsing oordink eerder ' $n$ pastorale benadering wat 'n ineenvloeiing van die storie van God en die mensverhaal bewerk, waaruit troos as unieke uitkoms gebore sal word.

\section{DIE KRISIS VAN DOOD: DOOD IS DOOD IS DOOD ...}

Grondliggend aan die rousmart wat hierdie navorsing in gedagte het, is die biologiese/fisieke dood van 'n naasbestaande. Hoewel daar weinig nuut is wat oor die dood gesê kan word, kan dit ook nie fenomenologies oor die hoof gesien word in ' $n$ artikel van dié aard nie.

Die opskrif van hierdie gedeelte poog om uitdrukking te gee aan die gevoel van vergeefsheid en algehele hopeloosheid waarmee mense gelaat word wanneer die dood 'n geliefde eis. Dit maak derhalwe nie saak hoe ons oor iemand se dood dink, praat of handel nie - niks keer die situasie om nie. Juis dít is moontlik die pynlikste aspek, maar ook die belangrikste fenomenologiese eienskap, van die dood. Freeman (2005:3) se onderskeid tussen biologiese, sosiale en fisiologiese dood onderstreep dat fisieke dood die laaste sê het. Geliefdes kan weens siektes soos vigs of orgaanversaking 'sosiaal' of 'fisiologies' sterf, maar niks is so finaal soos die biologiese afsterwe van 'n naasbestaande nie.

Die ervaring van die dood word uiteraard beïnvloed deur faktore soos die omstandighede waarin iemand fisiek sterf, en ook wie dit is wat sterf. Hier kom sake soos siekte, moord, selfmoord, ongelukke en terreuraanvalle ter sprake, asook wie verloor word: ouer, kind, eggenoot, en so meer (Wright 2003:268). Die ervaring van dood word voorts beïnvloed deur wie dit is wat treur: volwassenes of kinders, mans of vroue, ensovoorts, aangesien geslag en ouderdom ook ' $n$ bepaalde rol in die verskynsel van rou te speel het (kyk byvoorbeeld Marx (2007) oor die spesifieke behoeftes van kinders wat rou). Selfs kulturele agtergrond en die ingesteldheid jeens die dood binne bepaalde kultuurverbande sal ' $n$ faktor wees in die ervaring van dood (Corr, Nabe \& Corr 2003). Die bepaalde implikasies van die sterwensomstandighede, die verwantskap met die naasbestaandes, en die geslag en ouderdom van diegene wat rousmart beleef, lê egter buite die omvang van hierdie navorsing. Wat wél vir hierdie studie belangrik is, is die beginsel dat, alles in ag genome, dood steeds dood bly. Dit is hierdie allesoorweldigende gewaarwording van verlies waarvan die pastoraat moet sin maak.

\section{ROUSMART AS REAKSIE OP DIE DOOD}

Rousmart is die term wat breedweg gebruik word om naasbestaandes se reaksie op die oorledene se dood te beskryf. Een omskrywing van rousmart is moontlik om te sê dat dit die sienbare en onsienbare smart is wat op die dood van ' $n$ geliefde volg. Ingevolge so 'n omskrywing sal die sienbare smart in die uiterlike reaksies wat mense op die dood toon, geopenbaar word. Hiermee is ons goed bekend: van Jesus se trane by Lasarus se dood (Joh 11:33 \& 38) tot die droefreaksies wat vandag nog by elke sterfbed en begrafnis gesien word. Onsienbare smart word geopenbaar in die emosionele en psigiese worsteling waarin die dood naasbestaandes dompel. Tog staan hierdie aspekte in ' $n$ noue verband met mekaar, en Hagman (2001:20) wys daarop dat '[o]utward reactions that accompany grief, have significance in the sense that they are representative of a person's struggle to assimilate to a changed personal or interpersonal reality resulting from loss'.

Hierdie twee sake maak grootliks die reaksie op dood uit, wat rousmart genoem word. Nader omskryf, sê Hagman (2001:24) dat rousmart die volgende omvat:

A varied and diverse psychological response to the loss of an important other. Mourning involves the transformation of the meanings and affects associated with one's relationship to the lost person, the goal of which is to permit one's survival without the other while at the same time ensuring a continuing experience of relationship with the deceased.

(Hagman 2001:24)
Hierdie navorsing konsentreer op die tese dat die proses van rousmart tot die transformasie van betekenisse moet lei: die betekenis wat die oorledene vir die naasbestaandes gehad het; die betekenis van vorige verhoudings; die betekenis van die dood, en hoe mense in die lig van hierdie haas onoorkomelike struikelblok moet lewe. In die proses van rou moet sorg gedra word dat hierdie betekenisse só verstaan en vertolk word dat dit mense in staat stel om sinvol sonder 'n geliefde te lewe.

\section{DIE NARRATIEWE BENADERING TOT TERAPIE}

Die term 'narratiewe terapie' (hierna ook 'narratief') het sedert die vroeë negentigs onder die aandag van die hulpverleningswetenskappe gekom. Die hoofeksponente van hierdie benadering is twee kliniese terapeute, Michael White en David Epston. Hulle gesamentlike werk, Narrative means to Therapeutic Ends (1990), word reeds langer as 'n dekade as 'n standaardwerk op die gebied van die narratiewe benadering beskou. Volgens hierdie benadering funksioneer die begrip 'narratief' as 'n metafoor vir die begrip van die mens se lewe as 'n verhaal (Stassen 2004:41).

'n Narratief (verhaal) ontstaan volgens Morgan (2000:5) in mense se lewens na aanleiding van gebeure wat mettertyd in volgorde volgens ' $n$ bepaalde plot ontwikkel het. Mense lei uiteindelik hulle lewens aan die hand van hierdie verhale en laat selfs hulle verwagtings van die lewe hierdeur bepaal. Hierbenewens word mense se lewensverhale ook deur hulle lewenskonteks en kultuur bepaal: 'Like clay thrown on a potter's wheel, we are shaped from the moment of our birth, not only by our family legacy, but by the culture that creates the way we see and talk about ourselves and the world' (O'Hanlon 1994:23). Hierdie sosiale diskoerse is medebepalend ten opsigte van lewensgebeure om die verhaal te vorm aan die hand waarvan mense hulle lewens verstaan en vertolk. Volgens Ganzevoort (2006:3) berus iemand se belewenis van 'n bepaalde gebeurtenis grootliks op die sosiale konstruksies wat mense in ' $n$ bepaalde verband rondom sekere verskynsels in stand hou. Die finaliteit van die dood sal dus saam met die sosiale diskoerse wat gemeenskappe op die dood nahou, 'n dominante narratief uitmaak, wat die toekomstige narratief van naasbestaandes op 'n bepaalde wyse beïnvloed.

Volgens White en Epston (1990:9-10) onderskei die narratief tussen dominante en alternatiewe verhale. Die dominante stories is gewoonlik die probleemdeurdrenkte verhale ('problemsaturated stories') wat die alternatiewe (positiewe) verhale oorskadu. Alle nuwe gebeure wat op die dominante verhaal/ gebeurtenis volg, word in die lig van laasgenoemde verstaan, wat tot ' $\mathrm{n}$ beperkende siening van die hede en toekoms kan bydra. Ná die dood van 'n geliefde kan alles dus in die skadu van die verlies gesien word, en kan die dood die res van die naasbestaandes se lewens oorskadu. Die transformasieelement van die narratiewe benadering lê daarin dat dit ook die alternatiewe (positiewe) verhale in mense se lewens na vore bring en versterk, sodat ' $n$ nuwe, positiewe verhaal geskep kan word wat die ou dominante verhaal vervang (White \& Epston 1990:15).

Die konstruksie van hierdie unieke uitkomste, of nuwe verhale van hoop, word deur die gebruik van verskeie strategieë aangehelp wat met verloop van tyd onder die noemer van die narratief ontwikkel het. Enkele hiervan word vervolgens vlugtig omskryf.

\section{Die terapeutiese houding van 'nie weet nie'}

Anderson en Goolishian (1992:29) meen dat die terapeutiese houding van 'not knowing - the client is the expert' een van die grondliggende houdings in die narratiewe benadering tot terapie is. Dít beteken dat die hulpverlener se eerste verantwoordelikheid dié van onbevange luisteraar is. Op 
hierdie wyse kry persone in beraad ' $\mathrm{n}$ 'stem' en die geleentheid om as kundiges van hulle eie narratief daardie narratief sonder voorbehoud te deel. Ganzevoort (2006:2) beklemtoon individue se eiesoortige ervaring van gebeurtenisse soos volg: 'The meaning of words does not exist outside of the conversations in wich it functions.' In die lig hiervan is dit noodsaaklik dat hulpverleners op hermeneutiese wyse luister, sonder om alles dadelik aan die hand van hulle eie verwysingsraamwerk te meet. Volgens Parry (1991:42) gaan hermeneutiese luister juis oor die aanvaarding van die verskillende perspektiewe wat mense op die lewe nahou, en van ander se begrip van die werklikheid. Vrae vanuit hierdie houding van 'nie weet nie' stimuleer veral persone in beraad om uiting te gee aan hoe hulle regtig hulle werklikheid ervaar. Derhalwe doen Freedman en Combs (1996:113) aan die hand dat daar voortdurend uit die posisie van 'nie weet nie' vrae gestel moet word om 'n vertelling aan te moedig wat ' $n$ getroue weerspieëling van die pastorant se ervaring is.

Dit dien ook in gedagte gehou te word dat nie alle persone met ewe veel gemak hulle verhale vertel nie. In hierdie verband wys Ganzevoort (2001:132) op persone wat in 'n sogenaamde 'prenarratiewe' toestand verkeer, hetsy omdat hulle as gevolg van trauma nie hulle verhaal kan verbaliseer nie, of omdat hulle nie vaardig is in die narratiewe kultuur nie. Die houding van 'nie weet nie' stimuleer narratiewe bevoegdheid, en moedig die vertel van verhale aan waarsonder die narratiewe proses lamgelê sou wees. Slegs wanneer mense hulle eie verhale vertel, kan hulle begelei word om weer beheer oor hulle eie narratiewe te neem (Parry 1991:42).

Wat rousmart betref, sal dít beteken dat die pastor nie die pastorale situasie met 'n stel standaardantwoorde op, of pasklaaroplossings vir, die probleem van rousmart kan benader nie, maar eerder met ' $n$ bereidheid om in die leefwêreld en belewenis van die treurende persoon in te beweeg. Die houding van 'nie weet nie' moedig dus pastorante aan om hulle eie 'waarheid' te vertel, en nie beïnvloed te word deur wat hulle dink die pastor wil hoor nie.

\section{Die probleem is die probleem}

Die narratief onderskei bepaald ook tussen die mens en die probleem wat in terapie ter sprake kom. Morgan (2000:24) meen mense se verhouding met ' $\mathrm{n}$ bepaalde probleem ís juis die probleem. O'Hanlon (1994:24) gaan hiermee akkoord deur te sê: '[T]he person is never the problem; the problem is the problem.' Hierdie verhouding met die probleem word geopenbaar in die diskoerse wat oor bepaalde verskynsels in stand gehou word. Mense se opvattings oor die dood, hoe hulle gaan oorleef sonder 'n geliefde, en so meer, vorm ' $n$ 'problem-saturated dominant story' (Morgan 2000:14). Hierdie dominante storie oefen beheer uit oor mense, en het ' $n$ bepaalde invloed op hulle denke, vermoëns en probleemhanteringsvaardighede. Wanneer hierdie verhale met betrekking tot probleme vertel word, begin daar egter ' $n$ proses van probleemoplossing, aangesien gesprek oor die probleem tot nuwe insigte daaroor aanleiding gee. Anderson en Goolishian (1988:372) gaan so ver as om die terapeutiese stelsel as ' $n$ 'problem-dissolving system' te beskryf.

Die pastor moet dus sensitief wees om die treurende persoon in beraad nie as byvoorbeeld 'melankolies' of 'onwillig om oor iemand se dood te $\mathrm{kom}^{\prime}$ te bestempel nie. Pastors moet nuuskierig wees oor die verhouding waarin pastorante met hulle opvattings oor die dood en verwante sake staan, om te begryp welke invloed dit op die treurende persoon het. Op hierdie wyse word die narratief ' $n$ doeltreffende instrument om die mag te verbreek wat ' $n$ bepaalde probleem/opvatting oor mense uitoefen en hulle daarvan weerhou om te herstel.

\section{Dekonstruksie}

Dekonstruksie verwys na die weg waarlangs die probleme wat mense lamlê, in die narratiewe proses afgebreek word om tot nuwe betekenis te kom. Dit is die 'losmaak en uitmekaarhaal van ' $n$ betekenissisteem om vir alternatiewe verstaan ruimte te skep' (Kotzé \& Kotzé 1997:8). Dekonstruksie geskied deur middel van vrae en gesprekvoering, waardeur persone gelei word om krities te besin oor waarhede, idees en praktyke wat as vanselfsprekend beskou word (Morgan 2000:45). Op hierdie wyse kyk mense vanuit 'n nuwe perspektief na ou waarhede, of na dít wat hulle altyd as waar ervaar het.

'n Persoon het miskien lewenslank die opvatting gehad dat ' $n$ lewe sonder ' $n$ naasbestaande nie moontlik sou wees nie, of dat hulle nie die dood van iemand na aan hulle sal kan 'hanteer' nie. Dekonstruksie bevraagteken die geldigheid van hierdie aannames, en wil die saadjie van nuwe moontlikhede by mense plant.

\section{Eksternalisering}

Eksternalisering en dekonstruksie word dikwels as twee kante van dieselfde munt in narratiewe literatuur hanteer. Die rede hiervoor is dat dekonstruksie grootliks deur eksternalisering moontlik gemaak word. Laasgenoemde verwys na die proses waarlangs persone en hulle probleme van mekaar losgemaak word. Eksternalisering vind plaas waar persone dit regkry om 'n gepaste naam aan ' $n$ probleem te koppel (O'Hanlon 1994:24). Wanneer die probleem deur ' $n$ selfstandige naamwoord gepersonifieer word, word dit' $n$ entiteit wat ontleed en bespreek kan word. Morgan (2000:33) wys daarop dat die geskiedenis en invloed van die geëksternaliseerde probleem op 'n persoon dan makliker nagevors kan word ten einde die invloed van die probleem aan bande te lê. Ook White en Epston (1990:63) meen dat ' $n$ probleem deur middel van sy invloed op mense voortbestaan. Wanneer dié invloed of mag beperk word, word die probleem ook bestuur.

Wat die pastoraat aan persone met rousmart betref, sou eksternalisering vermoedelik daartoe kan bydra om die invloed van 'die dood' of 'die alleenheid' te verstaan en te hanteer. Dit het dus die potensiaal om aan naasbestaandes 'n ruimte te bied om vrese en beperkende diskoerse oor verlies krities te beoordeel.

\section{Ko-konstruksie}

Dit behoort reeds duidelik te wees dat die narratief swaar op die ervaring en kundigheid van die persoon in beraad steun, en dat hierdie selfnarratiewe in ' $n$ groot mate moet help om nuwe narratiewe tot stand te bring. Hierdie benadering het ook implikasies vir die posisie van die hulpverlener.

Die narratief onthef die hulpverlener/terapeut van die rol van meganikus wat vanuit 'n posisie van 'weet' die 'regte antwoorde' moet verskaf om probleme op te los. Veel eerder word voorkeur verleen aan die begrip 'ko-konstruksie', wat die pastor in die rol van medereisiger op die pastorant se reis plaas (kyk ook Müller 2000). In hierdie denkraamwerk is die pastor en die pastorant medeverantwoordelik vir die skep van nuwe betekenisse. Amundson, Stewart en Valentine (1993:120) verduidelik dat die narratiewe benadering van die beskouing uitgaan dat persone in beraad die beste bevoeg is om hulle eie storie te skryf, 'and the therapeutic encounter simply seeks to place the pen in their hand'.

Bogenoemde beteken egter nie dat die teologiese rol van die pastor gemarginaliseer word nie. Uiteraard betree die pastor die pastorale situasie vanuit die verwysingsraamwerk van die Woord, en is dit heel waarskynlik dat pastorante juis pastors as medereisigers opsoek om uit laasgenoemde se geloofskennis en -ervaring te put. Ko-konstruksie beteken dus nie dat die pastor met 'n skoon lei na 'n persoon luister asof die Woord sy rigtinggewende gesag verloor het nie. Freedman en Combs (2002:198) meen ook dat die narratief nie beteken dat geen rigtinggewende leiding meer bestaan nie: 'This does not mean that 'anything goes.' Tradition, personal history and 'common sense' constrain us...'. Derhalwe verstaan die pastoraat kokonstruksie as ' $\mathrm{n}$ gesamentlike reis vanuit die rykdom van God 
se Woord. Dít bring egter die belangrike beginsel na vore dat die pastor nie die pastorale situasie met 'n klompie voorafgekose Bybeltekste kan benader nie, maar dat pastors hulleself waarlik as medereisigers beskou wat éérs luister voordat raad aangebied word.

\section{Alternatiewe verhale en unieke uitkomste}

Die vorming van alternatiewe verhale, en die konstruksie van unieke uitkomste, kan in ' $\mathrm{n}$ sekere sin as die doel van die narratief beskou word. Die omgang met mense se narratiewe is daarop gemik om tot die vind van unieke uitkomste vir bepaalde probleme by te dra. Morgan (2000:52) merk op dat sodanige unieke uitkomste 'n plan, handeling, gevoel, stelling, eienskap, begeerte, droom, gedagte, oortuiging, vermoë of verbintenis kan wees. Voorts kan unieke uitkomste in die verlede, hede en/of die toekoms lê. As sodanig staan 'n unieke uitkoms in diens van die alternatiewe/oorvertelde verhaal, wat beperkende diskoerse nuut bekyk. Volgens O'Hanlon (1994:19-29) is dít waar die narratief in wese tot sy reg kom. Hieroor bevind Van Wyk en Marais (2005:19) ook die volgende: 'Wanneer die dinamiese interaksie tussen verlede en hede plaasvind, spring daar 'n vonk oor na die toekoms en word nuwe alternatiewe visioene van die toekoms oopgesluit.'

Bogenoemde is die rigting waarin ' $\mathrm{n}$ narratiewe omgang met treurende persone wil beweeg, naamlik om hulle stories oor die dood en oor hulle geliefdes aan te wend om nuwe, vertroostende verhale tot stand te bring wat hulle in staat sal stel om met hulle verlies saam te lewe.

\section{DIE NARRATIEF VANUIT ‘N PASTORALE PERSPEKTIEF}

Uit voorafgaande behoort dit duidelik te wees dat die narratie potensiaal inhou vir die begeleiding van persone wat in die beperkende diskoers van rousmart vasgevang geraak het. Vir die gereformeerde pastoraat is dit egter belangrik om daarop te let dat die narratief as benadering teen die agtergrond van die wegbeweeg van die modernistiese benadering tot die wetenskap ontstaan het. Grondliggend aan die narratief is ' $n$ postmoderne paradigma wat nie sonder meer met alle vorme van hulpverlening gepaar kan word nie. Dit is dus verstaanbaar dat pastorale teoloë 'n epistemologiese sensitiwiteit bepleit wanneer die narratief in die pastoraat gebruik word (kyk Janse van Rensburg 2000:62. Bezuidenhout 2005; Senekal 2006:134-146). In die gereformeerde tradisie word die pastoraat tradisioneel as geloofs-en lewenshulp verstaan (Rossouw 1991:121; Louw 1998:58), waarin die Woord en gebed ' $n$ onontbeerlike rol speel. Een van die kritiese vrae in ' $n$ narratiewe pastoraat sou dan wees in watter rigting God iemand se storie wil oorskryf (Burger \& Simpson 1996:83). Die narratief, daarenteen, rus swaar op die filosofiese onderbou van die poststrukturalis Focault en die sosiolinguis Halliday (Milner \& O' Byrne 2002:10) waarin sogenaamde grand narratives (algemene, tydlose waarhede) se rol vervaag. In 'n konsekwent narratiewe (postmoderne) benadering sou die waarheid en gesag van die Skrif dus in gedrang kom.

Die narratief word egter in die raamwerk van hierdie navorsing as ' $n$ terapeutiese benadering gekwalifiseer, wat die Skrif (en die gesag daarvan) as uitgangspunt neem, maar wat die teksanalogie van die narratief ook ernstig opneem - naamlik die verhale van mense, naas die Godsverhaal soos die Bybel dit openbaar, oftewel 'zorg voor het verhaal van mensen in relatie tot het verhaal van God' (Ganzevoort \& Visser 2007:10). Dit sluit aan by onder andere Middleton en Walsch (1995) sowel as Lee (2004) wat die Bybel as die transformasieagent in die herverbeeldingsproses van ' $n$ bepaalde beperkende narratief beskou. Hierin verskil 'n pastoraal-narratiewe benadering van ' $n$ gewoon narratiewe benadering in die eng (postmoderne) sin van die woord: Daar word nie hoofsaaklik op die menslike potensiaal staatgemaak om probleemdeurdrenkte verhale te transformeer nie, maar eerder op die Godsverhaal soos dit in die Woord geopenbaar word. Hieroor sê Camery-Hoggat (2006:468):

It is not enough that we employ both the rational and the imaginative...Reason and imagination are organs of knowing.. $[B]$ ut in themselves they are empty of content. They are wrong whenever they try to account for truth...[W]ithout taking into account the ultimate reality of God.

(Camery-Hoggat 2006:468)

\section{SKRIFGEBRUIK IN DIE PASTORAAL- NARRATIEWE BENADERING}

'n Pastoraal-narratiewe benadering tot persone met rousmart sluit aan by Louw (1998:430) se gedagte van organiese Skrifgebruik. Die begrip 'organies' word hier gebruik om iets te verwoord van die beginsel dat die Skrif in die pastorale situasie eerder vertolk moet word as wat dit homileties of 'prekerig' gebruik word. Dít beteken dat die pastoraat nie ' $n$ bepaalde Skriftema op die situasie afdwing nie. Daar word eers na die tersaaklike verhale geluister, waarna die pastor en die pastorant saam na die Skrif luister om te hoor wat dit vir die eksistensiële situasie te sê het. Louw (1998:431) beklemtoon die belangrike beginsel dat hierdie skema nie beteken dat die mensteks die inhoud van die Woordteks bepaal nie. Wat metodies gesproke 'eerste' kom, kom nie noodwendig in beginsel en inhoud eerste nie. Daarom word die organiese gebruik van die Skrif nie los van gebed en die werking van die Heilige Gees beskou nie.

\section{ALTERNATIEWE VERHALE EN UNIEKE UITKOMSTE IN `N PASTORAAL- NARRATIEWE BENADERING}

In ' $\mathrm{n}$ pastoraal-narratiewe benadering tot die probleem van rousmart is die verwagting dat die inhoud van unieke uitkomste hoofsaaklik religieus sal wees. Van Knippenberg (2006:175) merk in hierdie verband op dat godsdiens ' $n$ bydrae ten opsigte van bemoediging kan lewer, deur te help om die onderbrekings in die teks van'n lewensverhaal wéér te lees - dié keer in die lig van die oorspronklike teks. Indien die Woordteks (oorspronklike teks) langs die mensteks oor die verskynsel van die dood geplaas word, is daar 'n rykdom alternatiewe narratiewe waartoe die pastorant gelei kan word. Unieke uitkomste in hierdie navorsing behels egter ook meer as net nuwe betekenisinhoude in die lig van die Woord. Omdat die narratief in wese 'n heuristiese of ontdekkende benadering is (Brunsdon 2006:201), word die proses van luister na, en fisieke én emosionele betrokkenheid by, persone in rou as deel van die unieke uitkoms beskou. In hierdie navorsing verwys troos na die uitkoms wat só bewerkstellig word.

Die troos wat só gestalte kry, verteenwoordig een van die belangrike uitkomste van ' $n$ pastoraal-narratiewe benadering tot rousmart. Vir vertrooste mense kry rou dan 'n naam en 'n nuwe perspektief, wat hulle in staat stel om die gaping in die verhaal wat hulle aan hulleself en ander mense vertel, te oorbrug (Van Knippenberg 2006:179). 'n Narratiewe benadering tot rousmart is daarom nie 'n poging om rou 'op te los en af te handel' nie. Dit hoop slegs om troos teweeg te bring wat treurende persone op die weg van rou sal kan help om betekenis aan die treurproses te gee, en só die rouproses draaglik te maak. Hierdie troos sal waarskynlik deur verskillende diskoerse beïnvloed word, wat soos volg toegelig kan word.

\section{TEOLOGIESE BESKOUINGE VAN TROOS}

Troos sou as een van die mikronarratiewe in die groter narratief van God se omgang met die mens beskryf kon word. Die begrip kom oor ' $\mathrm{n}$ wye spektrum van betekenis in sowel die $\mathrm{Ou}$ as die Nuwe Testament voor. In die Ou Testament is dit egter veral die Hebreeuse nâcham wat gebruik word as aanduiding van die troos waarna treurende persone ná verlies gesoek het (VanGemeren 1997:81). In Genesis 24:67 word dit byvoorbeeld gebruik om die uitwerking te beskryf wat die huwelik tussen Rebekka en Isak op laasgenoemde gehad het in die lig van sy moeder, Sara, se 
dood: 'So is Isak vertroos ná sy ma se dood.' (Gen 24:67, NAB; eie beklemtoning) In 2 Samuel 13:39 word dit gebruik om aan te dui dat Dawid oor Amnon se dood getroos is, en in Jesaja 40:1 weer as heilsaankondiging vir Israel, wat as volk van die Here ' $n$ identiteitsverlies ervaar het (Hanson 1995:13).

In die Nuwe Testament word onder andere die Griekse paraklesis gebruik om uitdrukking aan die begrip 'troos' te gee. Paraklesis word in regstreekse verband met die verkondiging van die evangelie en die werk van Jesus Christus gebring (kyk onder andere Rom 15:4; Fil 2:1; Heb 12:5) en dien as sambreelterm vir die handeling waardeur mense se hartseer versag word (Zodhiates 1993:1106). Die begrip paramuthéomai, soos dit in Johannes 11:19 verskyn, dui op 'n bepaalde toespitsing van troos in die aangesig van verlies. Die Jode wat kom om Marta en Maria te troos, doen dit weliswaar vanuit die Joodse tradisie (Beasley-Murray 1999:190), maar hulle vervul ongetwyfeld 'n funksie wat daarop afgestem is om deur die toon van empatie, Marta en Maria se hartseer te verlig (Borchert 1996:355).

Uit voorafgaande blyk dit dat troos in die Woord met verlies verband hou - hetsy die verlies van ' $n$ naaste of van dít wat sin aan iemand se bestaan verleen het. Waar troos ter sprake kom, word lyding dus voorveronderstel (Polspoel 2006:182). Die ervaring van troos kom in die spel (word geaktiveer) deur die onderlinge betrokkenheid van mense sowel as deur die vertel van hoopvolle alternatiewe narratiewe. Dit is opvallend dat die Griekse paramuthéomai op die handeling van 'to speak kindly, soothingly, to comfort' dui (Zodhiates 1993:1110). Troos word derhalwe nie net deur teenwoordigheid en betrokkenheid teweeggebring nie, maar ook deur onderlinge gesprek wat die seer verlig.

In die Christelike tradisie is hierdie troosgesprek veral op twee sake gerig. Enersyds wil dit die verbondstrou van God aan die noodlydende toesê. Die Woord openbaar God se besondere gerigtheid op diegene wat voel dat die lewe se aanslae hulle oorweldig. In sy belofte aan die mens (verbond) is sowel die goed as die kwaad wat met mense gebeur, verreken, en kan die mens dus in 'n routydperk juis aan God se trou bly vashou (Janse van Rensburg 1996:154; König 2002:170)

Andersyds wil die Christelike tradisie rousmart verlig deur klem te lê op die eskatologiese bestemming van die gelowige. Persone in rousmart word nie net getroos deur die bystand wat hulle van ander ontvang nie, maar veral deur die versekering dat hulle geliefde 'ergens zijn' (Polspoel 2006:183). In 1 Korintiërs 15 plaas Paulus die opstanding van Christus en dié wat in Hom glo, as middelpunt van die Christelike prediking en geloof (Barret 1994:347). Hierdie opstanding loop uit op 'n werklikheid wat ewig en anders is as die aardse bestaan (1 Pet 1:3-4), en waarvan die heerlikheid in die teenwoordigheid van God self lê (Open 21:8). In hierdie verband keer die Bybelse diskoers oor die opstanding van die dooies, die mens se beperkende diskoers oor die dood netiies om. Die sterwe word in Christus ' $n$ wins (Fil 1:21), en dít dien ook as troos vir hulle wat agterbly.

Hierdie troos word nie net in die Skrif verwoord nie, maar ook in die sekondêre narratiewe van die gereformeerde geloofstradisie (belydenisskrifte). Dit word veral duidelik uit die Heidelbergse Kategismus se eerste vraag en antwoord, waar lewe en sterwe albei in die visier kom, sowel as die verskansing daarvan in Christus. Venter $(1991: 51,53)$ toon bevredigend aan dat daar bepaalde pastorale toepassingsmoontlikhede ten opsigte van troos in die belydenisskrifte is wat deur die pastoraat ontgin kan word.

Die Christelike narratief is dus na sy aard en wese' $n$ troosnarratief wat met vrug in die rousmartgesprek aangewend kan word om nuwe betekenisinhoude te gee aan die beperkende diskoerse oor verlies en die dood.

\section{TROOS AS HEILSTOESEGGING; PASTORAAT AS HEILSBEMIDDELING}

In ' $\mathrm{n}$ gereformeerde benadering tot die pastoraat dien die beginsel dat die pastorale proses ' $\mathrm{n}$ trialogiese karakter het (dit wil sê ' $\mathrm{n}$ drieledige verhouding mét bemiddeling is) as uitgangspunt. In die pastorale gesprek is die Heilige Gees die beïnvloedingsfaktor (Louw 1998:304) wat die heilstoesegginge van God, soos dit in die pastoraat oorgedra word, aan die hart van die pastorant waar maak. Hierdie 'counselling alliance' (Pembroke 2006:62) is in ' $n$ Christelike benadering tot die narratief aan die pneumatologie onderworpe, met ander woorde dat Christus deur sy Gees by die pastorale gesprek betrokke is om, in hierdie geval, die troos te bemiddel. Pieterse (1993:5) verwys na 'n sogenaamde 'teologiese ruimte' wat in verband met die pastorale gesprek voorsiening maak dat God self na sy welbehae kan spreek. Indien God se verhaal in die pastoraalnarratiewe proses langs die verhaal van die mense geplaas word, het die proses dus ' $n$ heilsbemiddelende karakter. Die pastor wil deur middel van hermeneutiese luister en die fasilitering van die oorvertel van verhale, God se troos aan die pastorant bemiddel. Hierin lê die eiesoortigheid van die pastoraat as hulpverlening immers opgesluit: dat dit die gebeure van heilskonkretisering vanuit die eiesoortige Christelike perspektief van troos toelig (én bemiddel) (Louw 1998:8). Dít is wat die pastorant uiteindelik bemagtig om getroos te lewe.

\section{PRAKTIESE GESTALTES VAN TROOS: ENKELE MERKERS VIR `N PASTORAAL- NARRATIEWE BENADERING TOT PERSONE MET ROUSMART}

In die lig van voorafgaande kan daar nou gepoog word om aan te dui watter gestalte troos in die pastoraal-terapeutiese begeleiding van die treurende persoon kan aanneem.

\section{'n Goeie verhouding}

Bryant-Jefferies (2006:9) maak die gevolgtrekking dat '[b]y offering someone a non-judgemental, warm and accepting, and authentic relationship, that person can grow into a fresh sense of self in which their potential as a person can become more fulfilled'. ' $n$ Pastoraal-narratiewe benadering veronderstel naamlik dat die pastor bereid sal wees om in ' $n$ opregte verhouding met die pastorant te tree, wat die ruimte skep vir die vertel van verhale. Volgens Veltkamp (1988:111) plaas die narratiewe benadering die pastor in die posisie van die hoeder (oppasser) van iemand se verhaal. Grondliggend hieraan is ' $n$ egte verhouding. Dít dien as die saad van troos, aangesien die pastor iemand is wat tyd maak en moeite doen om iemand se verhaal van verlies aan te hoor én daarmee te handel.

\section{Geestelike nabyheid}

Sarot (2006:168) beweer dat troos in die pastorale hooffokus van geestelike nabyheid gestalte kry. Hierdie geestelike nabyheid word geopenbaar in die simpatie, empatie en deernis waarmee pastors hulle in treurende persone se situasie inlaat. Geestelike nabyheid kan ten beste gesien word in die wyse waarop Jesus by Marta en Maria met die dood van hulle broer Lasarus teenwoordig was (Joh 11). Jesus openbaar ' $n$ deernisvolle teenwoordigheid (Lincoln 2005:326), wat duidelik blyk uit die feit dat Hy saam met die susters en Jode huil (kyk Joh 11:33, 35). Sarot (2006:172) wys daarop dat hierdie gebaar van Jesus uiteindelik straks belangriker as Lasarus se opwekking uit die dood kon wees.

\section{Woorde oor verlies}

Die veilige ruimte van ' $n$ goeie verhouding en geestelike nabyheid baan die weg vir die aanhoor van die treurende persoon se narratief. Hoewel die narratiewe benadering in wese nie gestruktureerd is nie, meen Müller (2000:72) dat die narratief tóg aan die hand van verskillende bewegings kan ontvou. Hierdie bewegings is egter nie klinkklaar van mekaar te skei nie, en kan oorvleuel. Die gesprek kan selfs heen en weer tussen die verskillende bewegings spring. Met betrekking tot die situasie van verlies, sou die volgende bewegings onderskei kon word: 
- Die aanhoor van die noodverhaal

Waarin is vertellers se nood geleë? Hoekom worstel hulle in hulle bepaalde situasie met hierdie verlies? Om te luister na die noodverhaal beteken om te probeer hoor hoekom mense staan waar hulle op daardie oomblik staan.

- Die aanhoor van die verledeverhaal

Hier word geluister na die verledeverhaal waarin die noodverhaal veranker is. Watter plek het die oorledene in die treurende persone se lewe ingeneem? Hoe verstaan hulle die dood, en watter verwagtings koester hulle vir 'n toekoms sonder die geliefde? Dít is enkele sake wat waardevolle insig kan bied in hoekom ' $n$ bepaalde narratief bestaan.

- Die oorvertel van die verledeverhaal

Met hierdie beweging word die begin van troos as unieke uitkoms waarskynlik sigbaar. Die belangrike uitdaging is die herformulering van problematiese narratiewe en opvattings. Aangesien dít ook die rede is hoekom mense in negatiewe diskoerse vasval, moet hierdie verhale wéér vertel word terwyl die troosperspektiewe vanuit die Godsverhaal en die Christelike tradisie daarby ingeweef word. Hierdie beweging van die narratiewe pastoraat is ' $\mathrm{n}$ opwindende onderneming.

- Die konstruksie van 'n troosvolle toekomsverhaal

Die uitkoms van die rouproses wat in hierdie artikel voorgestaan word, is dié van troos. Dit beweeg weg van die veronderstelling dat dit die pastoraat se taak is om toe te sien dat mense 'suksesvol' rou. Die konstruksie van 'n troosvolle toekomsverhaal impliseer dat ' $n$ ervaring van troos gefasiliteer moet word. Voormelde narratiewe proses ís juis so 'n ervaring waardeur mense op die pad van rou gehelp kan word, terwyl hulle nuwe betekenis aan die verskynsel van verlies begin heg. Die konstruksie van 'n troosvolle toekomsverhaal waarin treurende persone getroos kan leef, word as 'n langtermyndoelwit in die vooruitsig gestel. Dit laat steeds ruimte vir 'n oop einde aan die rouproses, wat erken dat ons geliefdes altyd deel van ons unieke verhale sal bly.

\section{GEVOLGTREKKING}

In die huidige denkklimaat wat van vaste konstrukte wegbeweeg, moet die pastoraat ook nuut dink oor die wyse waarop persone in rousmart begelei word. Pastors moet heel moontlik meer beskeie oor hulle rol dink, en hulle nie meer in die rol van geestelike meganikus sien nie, maar eerder as hoeder van mense se rouverhale, en as medereisiger wat bereid is om by mense se verhale oor die dood en hoe dit hulle raak, betrek te word. Om vertroostend saam te reis, is waarskynlik meer haalbaar as om 'toe te sien' dat mense 'suksesvol klaar rou'. Hiervoor is 'n pastoraal-narratiewe benadering 'n goeie metode om troos, soos dit in die groot narratief oor God verwoord word, aan hartseer mense te bemiddel.

\section{LITERATUURVERWYSINGS}

Amundson, J., Stewart, K. \& Valentine, L., 1993, 'Temptations of power and certainty', Journal of Marital and Family Therapy 19(2), 111-123.

Anderson, H.D. \& Goolishian, H., 1988, 'Human systems as linguistic systems: Preliminary and evolving ideas about the implications for clinical theory', Family Process 27(4), 371-393.

Anderson, H.D. \& Goolishian, H., 1992, 'The client is the expert. A not knowing approach to therapy', in S. McNamee \& K. Gergen, Therapy as Social Construction, pp. 24-37, SAGE, Londen.

Barret, C.K., 1994, The first epistle to the Corinthians, 2de uitgawe, A \& C Black, Londen.

Beasley-Murray, G.R., 1999, Word Biblical commentary. John, 2de uitgawe, Thomas Nelson Publishers, Nashville.

Bezuidenhout, J.P., 2005, 'Volwassewording as problematiek in pastorale konteks', DTh-proefskrif, Universiteit van die Vrystaat.
Borchert, G.L., 1996, The New American Commentary, Vol 25a: John 1-11, Broadman \& Holman Publishers, Nashville.

Brunsdon, A.R., 2006, 'Pastoraat aan die afgetrede egpaar deur kanker geaffekteer. 'n Narratiewe benadering', PhDproefskrif, Universiteit van die Vrystaat.

Bryant-Jefferies, R., 2006, Counselling for death and dying. Personcentred dialogues, Radcliffe Publishing, Oxford.

Burger, C. \& Simpson, N., 1996, Poorte vir die genade, Lux Verbi, Kaapstad.

Camery-Hoggat, J., 2006, 'God in the plot. Storytelling and the many-sided truth of the Christian faith', Christian Scholars Review xxxv(4), 461-470.

Corr, C.A., Nabe, C.M. \& Corr, D.M., 2003, Death and dying. Life and living, 4de uitgawe, Thomson Wadsworth, Belmont.

Freeman, S.J., 2005, Grief and loss. Understanding the journey, Thomson Brooks/Cole, Belmont.

Freedman, J. \& Combs, G., 1996, Narrative therapy. The social construction of preferred realities, Norton, New York.

Freedman, J. \& Combs, G., 2002, Narrative therapy with couples ... and a whole lot more!, Dulwich Centre Publications, Adelaide.

Ganzevoort, R.R., 2001, Reconstructies: Praktisch-theologisch onderzoek naar de verhalen van mannen over seksueel misbruik en geloof, Kok, Kampen.

Ganzevoort, R.R., 2006, 'The social construction of revelation', International Journal of Practical Theology 8(2), 1-14.

Ganzevoort, R.R. \& Visser, J., 2007, Zorg voor het verhaal: Achtergrond, methode en inhoud van pastorale begeleiding, Meinema, Zoetermeer.

Hagman, G., 2001, 'Beyond decathexis: Towards a new psychoanalytic understanding and treatment of mourning,', in R.A. Neimeyer (red.), Meaning reconstruction $\mathcal{E}$ the experience of loss, pp. 13-32, American Psychological Association, Washington.

Hanson, P.D., 1995, Interpretation. A Bible commentary for teaching and preaching. Isaiah 40-66, John Knox Press, Louisville.

Janse van Rensburg,J., 1996, 'Verbond en pastoraat. Perspektiewe vir die ontwerp van 'n paradigma', NGTT XXXVIII, 152165.

Janse van Rensburg, J., 2000, The paradigm shift, Van Schaik, Pretoria.

König, A., 2002, God, waarom lyk die wêreld só?, Lux Verbi BM, Parow.

Kotzé, E. \& Kotzé, D.J., 1997, 'Social construction as a postmodern discourse: An epistemology for conversational therapeutic practice', Acta Theologica 17(1), 27-50.

Kübler-Ross, E., 1969, On death and dying, Macmillan Ltd, New York.

Kübler-Ross, E. \& Kessler, D., 2005, On grief and grieving: Finding the meaning of grief through the five stages of loss, Simon \& Schuster, Londen.

Lee, J.A., 2004, 'Agency and purpose in narrative therapy: Questioning the postmodern rejection of metanarrative, Journal of Psychology and Theology 32(3), 221-231.

Lincoln, A.T., 2005, The Gospel according to St. John, Hendrickson Publishers Inc., New York.

Louw, D.J., 1998, Pastoraat as vertolking en ontmoeting, 3de uitgawe, Lux Verbi, Kaapstad.

Marx, J., 2007, ‘Pastorale berading aan kinders met onverwerkte rousmart', MA-verhandeling, Noordwes-Universiteit.

Middleton, J.R. \& Walsch, B.J., 1995, Truth is stranger than it used to be: Biblical faith in a postmodern age, Intervarsity Press, Downers Grove.

Milner, J. \& O'Byrne, P., 2002, Brief Counselling. Narratives and solutions, Palgrave, New York.

Morgan, A., 2000, What is narrative therapy?, Dulwich Centre Publications, Adelaide.

Müller, J., 2000, Reisgeselskap, Lux-Verbi BM, Wellington.

Müller, J., 2005, 'A postfoundationalist, HIV-positive practical theology', Praktiese Teologie in Suid-Afrika 20(2), 72-88.

Nadeau, J.W., 1998, Families making sense of death, Sage Publications, Thousand Oaks. 
O'Hanlon, B., 1994, 'The third wave. Can a brief therapy open doors to transformation?', The Family Networker Nov/Dec, 19-29.

Parry, A., 1991, 'A universe of stories', Family Process 30, 37-54.

Pembroke, N., 2006, Renewing pastoral practice. Trinitarian perspectives on pastoral care and counselling, Ashgate, Aldershot.

Pieterse, H., 1993, Praktiese teologie as kommunikatiewe handelingsteorie, RGN-Uitgewers, Pretoria.

Polspoel, A., 2006, 'Troost bij sterven en rouw', Praktische Theologie 33(2), 182-187.

Rossouw, P.J., 1991, 'Die diakonologie - Teologiese basisvrae', Tydskrif vir Christelike Wetenskap 1/2, 120-133.

Sarot, M., 2006, 'En Jezus weende. Kleine filosofie van de troost', Praktische Theologie 33(2), 165-172.

Senekal, D.P., 2006, 'Die funksionering van Bybelse inhoude in 'n narratief-pastorale gesprek', Praktiese Teologie in SA 21(2), 134-146.

Smith, W. \& Dreyer, Y., 2000, 'Pastoraat in rousmart as bewuste kommunikasie van die emosies van rousmart', HTS Teologiese Studies/Theological Studies 56(1), 273-294.

Spiegel, Y., 1977, The grief process, Abingdon Press, Nashville.
Stassen, S.L., 2004, 'Die benutting van die Rutverhaal in die pastoraal-terapeutiese begeleiding van onderdrukte en getraumatiseerde vroue', MTh-verhandeling, Universiteit van die Vrystaat.

VanGemeren, W.A. (red.), 1997, New international dictionary of Old Testament theology and exegesis, vol. 1, Zondervan, Grand Rapids.

Van Knippenberg, T., 2006, 'Troost en religie', Praktische Theologie 33(2), 173-182.

Van Wyk, C. \& Marais, F., 2005, 'Ore om God se alternatiewe verhaal te hoor', Kruisgewys 5(3), 17-20.

Veltkamp, H.J., 1988, Pastoraat als gelijkenis: De gelijkenis als model voor pastoraal handelen, Kok, Kampen.

Venter, C.J.H., 1991, "“Jou enigste troos": Pastorale perspektiewe en motiewe uit die Heidelbergse Kategismus', In die Skriflig 25(1), 47-49.

White, M. \& Epston, D., 1990, Narrative means to therapeutic ends, W.W.W. Norton \& Co., New York.

Wright, H.N., 2003, Crisis and trauma counselling, Regal Books, Ventura.

Zodhiates, S., 1993 (red.), The complete Word study dictionary. New Testament, AMG Publishers, Chattanooga. 